\title{
REGIONAL GROWTH AND CONVERGENCE IN SPAIN: IS THE DECENTRALISATION MODEL IMPORTANT?*
}

\author{
E. Macarena HERNÁNDEZ-SALMERÓN - Carlos USABIAGA
}

(Received: 31 July 2016; revision received: 12 March 2017; accepted: 15 April 2017)

\begin{abstract}
This paper deals with the effects of political decentralisation on economic growth in Spain, an issue that has generated heated debates in recent decades. Our analysis of the last three and a half decades, a period characterised by the weak narrowing of the income per capita gap within regions, does not offer conclusive results on convergence and points to the importance of alternative factors. Several proxies were used to capture the decentralisation process. We also studied some potential interactions between decentralisation and other variables. All in all, our empirical evidence shows robustly that transferring more responsibilities to subnational governments does not significantly affect growth in any sense.
\end{abstract}

Keywords: economic growth, convergence, decentralisation, Spanish regions

JEL classification indices: C23, H11, O47, R11

* We thank Pablo Álvarez de Toledo, Alejandro C. García-Cintado, Diego Martínez-López, Fernando Núñez, Daniel Oto-Peralías, María del P. Pablo-Romero, Julián Ramajo and Diego Romero-Ávila, as well as the participants at EcoMod 2016 Conference (Lisbon) for their valuable comments and suggestions. Carlos Usabiaga acknowledges financial support from the Spanish Ministry of Economics and Competitiveness under grant ECO2012-35430 and the Andalusian Council of Economics and Knowledge (SEJ-513 PAI Research Group).

Carlos Usabiaga, corresponding author. Professor of Economics at Pablo de Olavide University, Seville. Carretera de Utrera, Km. 1, 41013 Seville. Spain. E-mail: cusaiba@upo.es

E. Macarena Hernández-Salmerón, Economist at the Andalusian Council of Economics and Knowledge. E-mail: esperanzam.hernandez@juntadeandalucia.es 


\section{INTRODUCTION}

The approval of the Spanish Constitution (CE, henceforth) in 1978 marked the beginning of the development of what is called the State of the Autonomous Communities, with the establishment of 17 Autonomous Communities (CC.AA, henceforth). The decentralisation process involved the transfer of powers from the central government to the CC.AA. Nevertheless, not all the CC.AA have the same power and the speed of this devolutionary process has also been different among them. We can distinguish three types of CC.AA (Figure 1): the ones that used Article 143 of the CE, the ones that used Article 151 of the CE, and the Foral Communities. The CC.AA of Article 143 of the CE assumed a group of common competences at the beginning such as the promotion of regional economic development, public works, housing, railways and roads, ports and airports, agriculture and fishing, environmental protection, tourism, economic regulation, culture and social welfare, but education and health were not yet their responsibility. Meanwhile, the CC.AA of Article 151 of the CE, thought for the historical nationalities, gained more powers sooner, as did the foral ones, which also had their own
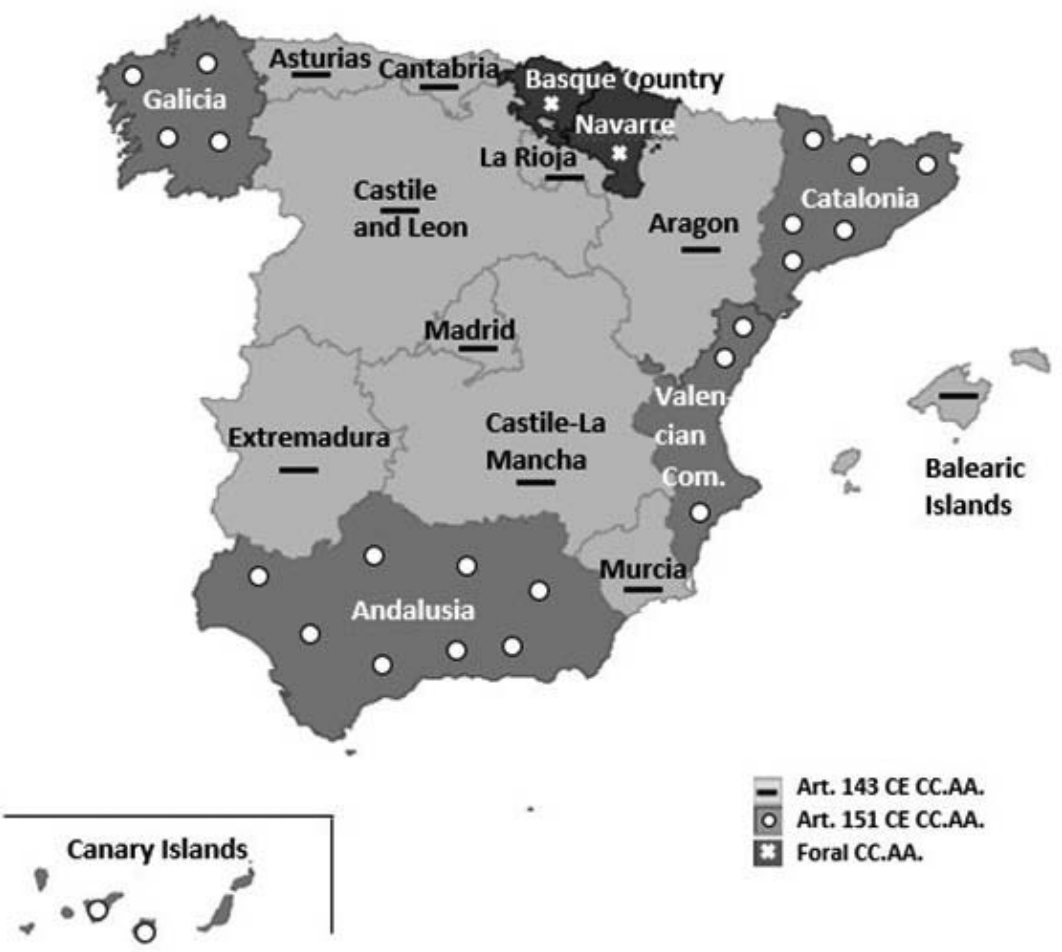

Art. 143 CE CC.AA.

- Art. 151 CE CC.AA.

: Foral CC.AA.

Figure 1. Subnational distribution in Spain: 17 Autonomous Communities 
fiscal and economic regimes. Two regions keep the taxes collected in their territories and transfer a quota to the central government. In contrast, in the rest of the regions taxes are collected by the central government, which gives those regions a share of these taxes to finance the tasks they perform.

The central administration takes care of foreign policy, defence, justice, social security, citizenship, immigration, and unemployment benefits, and it has a transversal power over the promotion of economic activity, as it sets the basis and coordinates the general planning of the economic activity.

In this paper, we test the convergence hypothesis and explore the potential effect of the decentralisation process on regional GDP per capita growth. We try to focus on the policy scope, that is, the range of policies for which a regional government has decision-making powers. The results seem to confirm the existence of conditional beta convergence, although at a very low pace. Traditional factors considered in regional convergence literature and new ones treated in this paper (such as decentralisation) do not appear to have had a statistically relevant role in the reduction of disparities within Spain, meaning that the convergence policy has not fulfilled its objective.

The rest of the study is organised as follows: Section 2 reviews the literature on the relationship between decentralisation and economic growth. Section 3 takes a look at the data and statistical sources, and explains the indicators used as proxies of decentralisation. Section 4 presents the econometric specification based on the system GMM (generalised method of moments) estimator for dynamic panels. In Section 5, the results from the empirical analysis are discussed. Finally, the last section concludes and summarises the most relevant outcomes of our research.

\section{OVERVIEW OF THE LITERATURE}

The meaning of decentralisation is not clear-cut and may vary. In general, it can be considered as a transfer of fiscal, political, and policy powers to subnational governments. Following Rodden (2004), we can consider decentralisation from this triple point of view, although he points out that the attempts to define and measure decentralisation have focused primarily on fiscal and to a lesser extent on policy and political authority.

The most outstanding empirical contributions study the relationship between economic growth and fiscal decentralisation ${ }^{1}$ using the balance of expenditures and revenues among governments as indicators, with mixed results. Our interest

For a more detailed analysis of the main contributions in this field, see the first two panels of the Appendix. 
in this particular field has to do with the analytical framework and the empirical methodology used in international and national literature. Basically, there are two groups of contributions. The first one, based on the seminal work of Davoodi Zou (1998), relies on the model of endogenous growth of Barro (1990), where the production function has multiple inputs, including private and public spending. Lin - Liu (2000) apply the augmented Solow model instead, and introduce fiscal decentralisation as an explanatory variable of the growth rate of output per capita. More recently, Asatryan - Feld (2015) applied a Bayesian model averaging approach. Ligthart - van Oudheusden (2017) used a "Barro-style", non-formally derived, growth regression.

The most used estimation methodology is the simple ordinary least squares (OLS) and the fixed effect (FE) estimator for panel data. Carrion-i-Silvestre et al. (2008) and Filippetti - Sacchi (2016) use the system GMM estimator in the context of decentralisation.

For Spain, Gil-Serrate - López-Laborda (2006) and Gil-Serrate et al. (2011) obtain a positive link between decentralisation and growth. Cantarero - Pérez (2009) only obtain a positive sign in the case of revenue decentralisation, not supporting a significant relationship between growth in GDP per capita and expenditure distribution among fiscal administrations. Carrion-i-Silvestre et al. (2008) found a negative effect at the aggregate economy-wide level. However, disaggregating the data leads to a positive effect on economic growth for those regions with the highest levels of fiscal and institutional decentralisation, and the opposite effect is found for those regions with the lowest levels of decentralised powers.

Turning to a wider concept of decentralisation, ${ }^{2}$ introducing political and/or administrative powers, its link with economic growth was studied by authors such as Castles (1999), Rodríguez-Pose - Ezcurra (2011), and Ezcurra - Rodríguez-Pose (2013), with their results suggesting a lack of or even a negative statistical relationship between political decentralisation and economic growth. In contrast, Filippetti - Sacchi (2016) find that the pro-growth effects of fiscal decentralisation depend critically on the authority of subnational governments: tax decentralisation leads to higher (lower) rates of economic growth when coupled with high (low) administrative and political decentralisation. Our paper basically tries to make a contribution to this line of research based on a wide notion of decentralisation.

An alternative approach can be found in Rodríguez-Pose - Bwire (2004). They assess the horizontal link between devolution and regional economic growth in six national contexts (Germany, India, Italy, Mexico, Spain, and the United

2 See the third panel of the Appendix. 
States) using regression models in order to test whether changes in cross-regional differences in growth patterns within each country considered can be attributed to changes in levels of regional autonomy. The results suggest that contrary to the expectations of "devolutionists", the degree of devolution is in most cases, Spain among them, irrelevant for economic growth - an empirical finding that is consistent with the hypothesis that we aim to test in our paper, using a different analytical framework.

\section{DATA AND STATISTICAL SOURCES}

As a first step, we had to build a long historical series for the period 1980-2014. The Spanish Statistical Institute (INE) does publish data of the GDP of the CC.AA in the Contabilidad Regional de España (Spanish Regional Accounts), but they refer to different bases and methodologies. For the population, we used the data referred to July 1 from the publication Cifras de Población of INE.

In Figure 2, we plotted the situation of each region in 1980 and 2014, compared to the average. Extremadura is the relatively poorest region in both 1980 and 2014. Andalusia and Castile-La Mancha are also in the bottom of the figure. In contrast, the development of Madrid can be highlighted, which overtook
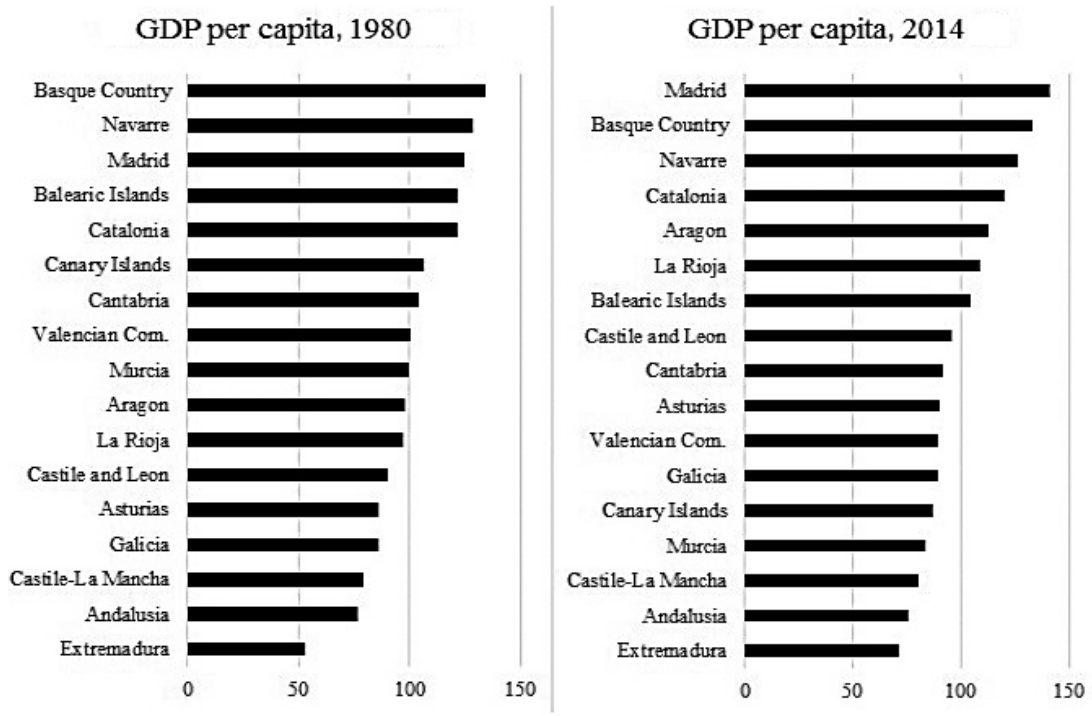

Figure 2. GDP per capita of Spanish regions in 1980 and 2014

Note: Average $=100$ for each year. 
Basque Country and Navarre, and became first in the ranking of the wealthiest regions. In the middle, some minor changes can be observed. Nevertheless, it must be mentioned that all the regions grew, slightly closing the gap between the poorest and the wealthiest.

The determinants of GDP per capita that we consider are the ones used by Mankiw et al. (1992): population growth and investment rate, obtained from the database of the Instituto Valenciano de Investigaciones Económicas (Valencian Institute of Economic Research, IVIE), with information for the period 1980$2012{ }^{3}$ and defined as the rate of gross non-residential investment over GDP. For human capital, the proxy used is the rate of working age population with higher education (post-secondary and over), also extracted from the IVIE database, and complemented with data from the Encuesta de Población Activa (Labor Force Survey) of INE. We also introduced control variables to try to capture structural differences among the regions, as is usual in convergence studies. Specifically, we consider two: the weight of employment in agriculture over total employment in order to capture the role played by economic structure, as in Barro - Sala-iMartin (1991) or Maudos et al. (1998), and the unemployment rate to control for the effects of the business cycle, as in De la Fuente (2002).

In the second part of our analysis, which constitutes our main empirical contribution, we use several variables related to the powers assigned to the CC.AA as proxies for regional authority over policy-making. ${ }^{4}$ The Spanish Ministry of Finance and Public Administration offers a list of the Royal Decrees of transfers of competences to the seventeen CC.AA, sorted out by date, and a summary table. ${ }^{5}$ We have built three series from that information: the first contains the total number of powers as they were assigned to each CA, the second cumulates those data over the period, and the third normalises the second series by the average of the 17 CC.AA for each period to capture the effect of having a greater or smaller degree of autonomy than the average.

Another option is not focusing on the total number of competences, but solely on the ones that the Ministry considers common, plus university and under-university level education, health, and social services (Table 1), 20 being the maximum number of these common competences. Considering these series, we have built a simple common competences index (CC Index), which takes a value of 1 when the number of common competences is $0-3$, a value of 2 when the region has between 4 and 7 competences, a value of 3 when there are between 8 and 11, a value of 4 between 12 and 15, and a value of 5 between 16 and 20 .

$3 \quad$ Fundación BBVA and IVIE (2014).

$4 \quad$ These series and the corresponding graphs are available from the authors upon request.

5 http://www.seat.mpr.gob.es/portal/areas/politica_autonomica/traspasos.html 
Table 1. Proxies for regional authority over policy-making

\begin{tabular}{l|l}
\hline $\begin{array}{l}\text { Number of competences } \\
\text { as they were transfered }\end{array}$ & Ranges from 0 to 189 \\
\hline $\begin{array}{l}\text { Cumulated number of } \\
\text { competences }\end{array}$ & Ranges from 0 to 189 \\
\hline $\begin{array}{l}\text { Normalised cumulated } \\
\text { number of competences }\end{array}$ & Ranges from 0 to 5 \\
\hline $\begin{array}{l}\text { Cumulated common } \\
\text { competences }\end{array}$ & Ranges from 1 to 20 \\
\hline $\begin{array}{l}\text { Common Competences } \\
\text { Index }\end{array}$ & $\begin{array}{l}\text { Ranges from } 1 \text { to } 5 \\
1: 0-3 \text { common competences } \\
2: 4-7 \text { common competences } \\
\text { 3: 8-11 common competences } \\
4: 12-15 \text { common competences } \\
5: 16-20 \text { common competences }\end{array}$ \\
\hline $\begin{array}{l}\text { Weighted Common } \\
\text { (Numpetences Index } \\
\text { weight of each area) }\end{array}$ & $\begin{array}{l}\text { Health (45\%): Implementation of legislation on pharmaceuticals, } \\
\text { prison health care, health system (hospitals, staff, medical centers, } \\
\text { etc.). } \\
\text { Education (30\%): Religion teachers, teachers in penal institutions, } \\
\text { student insurance, scholarships and study assistance, standardisation } \\
\text { and validation of foreign academic qualifications in non-university } \\
\text { higher education, non-university and tertiary education. } \\
\text { Social services (10\%): Labor and social security inspection, social } \\
\text { services policies. } \\
\text { Productive sectors (10\%): Management of the Spanish Agricultural } \\
\text { Guarantee Fund, professional diving, nuclear facilities of 2nd and } \\
\text { 3rd categories. } \\
\text { Employment (3\%): Occupational professional training, active em- } \\
\text { ployment policies, vocational training for employment, regional em- } \\
\text { ployment services. } \\
\text { Justice (2\%): Human and material resources of the administration } \\
\text { of justice. }\end{array}$ \\
\hline
\end{tabular}

We have also divided the 20 common competences into six areas: health (3 competences), education (7 competences), social services (2 competences), productive sectors ( 3 competences), employment (4 competences), and justice (1 competence). Each of these areas has a weight (45\%, 30\%, 10\%, 10\%, 3\%, and $2 \%$, respectively), derived from the average amount of public expenditure in each field. Finally, we have weighted the cumulated common competences of each region, multiplying the number of competences assumed in each area by the corresponding weight. As it can be observed, we have tried to combine all the main possibilities in this respect, which is uncommon in this literature.

In the last part of our study, we focus the analysis on the interaction of the CC Index with several explanatory variables. In particular, we consider the investment rate, the percentage of working age population with higher education, the average years of schooling, the rate of entrepreneurship, and R\&D expenditure, 
as the Spanish regions have tools to promote them using their budgets. We will also consider the informal economy, as its reduction is a desirable policy for governments in general.

Data for the average years of schooling are obtained from the database of the IVIE. ${ }^{6}$ The rate of entrepreneurship is defined as the number of new companies created per ten thousand people, both series available from INE. This is the same source used for R\&D expenditure. Finally, the weight of the informal economy has been calculated on the basis of the data provided by Gómez-Antonio - Alañón (2004) and GESTHA-FURV (2014).

\section{ECONOMETRIC SPECIFICATION}

We will focus on well-known equations used empirically in this literature: the regressions à la Barro. In particular, and following the specification proposed by Durlauf et al. (2005), the growth equation to be estimated is the following:?

$$
\begin{gathered}
y_{i, t}=\beta \ln Y_{i, 0}+\varphi X_{i, t}+\pi Z_{i, t}+\theta_{t}+\varepsilon_{i, t} \\
\text { with } \quad \varepsilon_{i, t}=\alpha_{i}+u_{i, t}
\end{gathered}
$$

where $y_{i, t}$ is the GDP per capita growth in the period under study (1980-2014), $Y_{i, 0}$ is the initial GDP per capita and contains the convergence coefficient $(\beta), X$ is the vector that includes the classical determinants of the Solow (1956) and Mankiw et al. (1992) models, that is, population growth and physical and human capital. $Z$ is the vector that includes additional determinants, in our case, the different proxies for the degree of autonomy. $\theta_{t}$ represent time effects, $\alpha_{i}$ individual effects, and $u_{i, t}$ is the idiosyncratic error term. $i$ refers to the 17 CC.AA and $t$ to the period.

This equation will be estimated within the framework of a dynamic panel. We have opted for five-year averages to reduce the effect of short-term shocks and the business cycle and capture the long-term relationships among variables, avoiding the problem of non-stationarity of the data series, which would cause biased results.

The empirical strategy will be the following: (1) We estimate the MRW model in order to test the existence of conditional convergence among Spanish regions; (2) we introduce in the growth equation the variables related to the degree of

$6 \quad$ Fundación Bancaja and IVIE (2014).

7 We use a log-specification in all our equations, except for those variables expressed in percentage, so that the estimates are less sensitive to outliers. 
autonomy; (3) we analyse the interaction of variables such as investment, education, entrepreneurship, R\&D expenditure, and informal economy with our CC Index to discover potential synergies among the set of regressors and how they actually affect the growth of GDP per capita. ${ }^{8}$ In that case, with interactions, the equation to be estimated would be the following:

$$
\begin{gathered}
y_{i, t}=\beta \ln Y_{i, 0}+\varphi X_{i, t}+\pi Z_{i, t}+\rho A_{i, t} *+B_{i, t}+\theta_{t}+\varepsilon_{i, t} \\
\text { with } \quad \varepsilon_{i, t}=\alpha_{i}+u_{i, t}
\end{gathered}
$$

representing $A$ and $B$ the variables that interact, which can be from the vector $X$ or $Z$. The parameters of interest are $\pi$ and $\rho$. If the marginal effect of variable $A$ increases with $B, \rho$ would be positive, although the total effect depends on the sign of $\pi$.

We will focus our attention on the system GMM estimator. ${ }^{9}$ In our paper, as the sample is small (17), there is a potential problem of instrument proliferation, as pointed out in Roodman (2009b), making some of the asymptotic results of the estimators and the specification tests inaccurate. To limit the number of instruments, we will use only certain lags.

\section{RESULTS}

\subsection{The Mankiw-Romer-Weil approach (MRW)}

In column (1) of Table 2, we show the results of our estimation based on the approach developed by Mankiw et al. (1992), over 7 five-year periods (1980-2014). We regressed the growth of GDP per capita, conditioned on the initial GDP per capita, population growth (plus the rate of technical progress and the rate of depreciation of physical capital), non-residential investment rate as percentage of GDP, and the rate of working age population with higher education. The negative and statistically significant sign associated with the initial GDP per capita confirms the existence of conditional beta convergence. ${ }^{10}$

For the rest of the variables, as the Solow model predicts, population growth has a negative and statistically significant impact on GDP per capita growth,

8 For a more detailed description of the specification of interaction models, see Friedrich (1982), Braumoeller (2004), or Brambor et al. (2006).

9 See Arellano - Bover (1995) and Blundell - Bond (1998). For its implementation with Stata, see Roodman (2009a).

10 For an overview of the literature on Spanish regional growth and convergence, see Hernández-Salmerón - Usabiaga (2016). 
while the percentage of working age population with higher education has a positive and statistically significant effect. In the case of the investment rate, the estimated coefficient has a positive sign, although of smaller magnitude than the one on human capital, and it is not statistically significant.

Finally, as for the control variables introduced, the rate of agricultural employment has an expected statistically significant negative sign, as in Mas et al. (1993), and the unemployment rate also shows a negative contribution, which is consistent with economic theory, as González-Páramo - Martínez-López (2003)

Table 2. Benchmark MRW model

\begin{tabular}{l|c|c}
\hline & $(1)$ & $(2)$ \\
\hline Initial GDP per capita & $-2.722^{*}$ & \\
\hline Initial GDP per capita for regions with higher degree & $(1.422)$ & \\
of autonomy & & $-2.815^{*}$ \\
\hline Initial GDP per capita for regions with lower degree & & $(1.405)$ \\
\hline of autonomy & & $-2.822^{*}$ \\
\hline Population growth & $-0.417^{* *}$ & $-0.414^{* *}$ \\
& $(0.159)$ & $(0.158)$ \\
\hline Investment rate & 0.039 & 0.040 \\
& $(0.031)$ & $(0.032)$ \\
\hline Working age population with higher education, \% & $0.060^{*}$ & $0.059^{*}$ \\
& $(0.030)$ & $(0.031)$ \\
\hline Agricultural employment rate & $-0.066^{* *}$ & $-0.067^{* *}$ \\
& $(0.024)$ & $(0.026)$ \\
\hline Unemployment rate & -0.039 & -0.044 \\
& $(0.035)$ & $(0.037)$ \\
\hline Constant & $30.325^{* *}$ & $31.313^{* *}$ \\
& $(14.248)$ & $(14.223)$ \\
\hline Number of instruments 1 & 89 & 89 \\
Arellano-Bond test order 1 & -2.60 & -2.61 \\
Arellano-Bond test order 2 & $(0.009)$ & $(0.009)$ \\
Sargan test & 0.74 & 0.73 \\
Hansen test & $(0.46)$ & $(0.465)$ \\
Number of observations & 62.14 & 62.56 \\
& $(0.874)$ & $(0.847)$ \\
& 10.49 & 1.70 \\
& $(1.000)$ & $(1.000)$ \\
& 119 & 119 \\
\hline
\end{tabular}

Notes: The dependent variable is real GDP per capita growth. Variables are five-year averages covering the period 1980-2014. Robust standard errors in parentheses. $* * * \mathrm{p}<0.01, * * \mathrm{p}<0.05,{ }^{*} \mathrm{p}<0.1$. All the results include time dummies, not reported for space reasons. System GMM estimator, option one-step, with all explanatory variables being treated as potentially endogenous. Time dummies are considered predetermined. Small sample correction and lag $(2,3)$ was applied, with xtabond2 package for Stata (Roodman 2009a). Robustness checks were also implemented, considering alternative specifications of GMM system, which can be provided by the authors upon request. 
pointed out. These results suggest that, ceteris paribus, regions with a higher ratio of workers employed in the primary sector and higher unemployment rate experienced lower GDP per capita growth than the rest.

Thus, in short, we could point out that certain features of the economic structure and inefficient labour markets appear to be harmful to the process of catching up among the regions. The specialisation in the least productive sectors such as agriculture conditions the attainable income level (steady-state), dragging potential economic growth. In contrast, human capital could favour growth. On this point, De la Fuente - Doménech (2016) suggest that the significant differences in the years of schooling probably explain the huge disparities in productivity, unemployment rate, and income per capita among Spanish regions. Furthermore, when they work with the information disaggregated by age ranges, they find that based on current patterns of schooling and in the absence of large migration flows, the prospects for further educational convergence between regions are scarce.

We also checked if the analysis of conditional convergence varies if we consider the degree of regional autonomy (column 2). For that purpose, the same estimation was implemented decomposing the initial GDP per capita into two variables. The first variable, initial GDP per capita for regions with a higher degree of autonomy, was obtained by multiplying the initial level of income by a dummy variable that took the value 1 if the region accessed autonomy using Article 151 of the CE or is a foral region, and 0 otherwise. The second variable, GDP per capita for regions with a lower degree of autonomy, was obtained by multiplying the initial GDP per capita by a dummy variable equal to 1 if the region accessed autonomy using Article 143 of the CE, and 0 otherwise. These results also confirm the existence of conditional beta convergence, with significant and similar coefficients, this last result being supported by the test of equality of coefficients. The results for the rest of the variables follow the aforementioned patterns.

\subsection{Effects of the degree of regional autonomy}

The estimation obtained in the first subsection constitutes our benchmark. In the present subsection, we will progressively introduce what we have considered as proxy variables for the degree of regional autonomy, so that we can assess the effect of the number of transferred competences on GDP per capita growth.

In most of the cases, the coefficient associated with initial GDP per capita decreases in comparison with our benchmark estimation when the decentralisation variable is taken into account. This may indicate that this variable had a positive contribution to the process of catching-up among regions. Let us analyse the results for each proxy. 
Table 3 shows a positive, though not statistically significant, relationship between the total number of powers assumed by regions and GDP per capita growth (column 1). When we consider either the total number of powers (column 2), or the common powers (column 4), both in cumulative terms, the coefficient is equal to zero, reflecting that neither of these variables explains GDP per capita

Table 3. Benchmark MRW model augmented with different proxies of decentralisation

\begin{tabular}{|c|c|c|c|c|c|c|}
\hline & (1) & (2) & (3) & (4) & (5) & (6) \\
\hline Initial GDP per capita & $\begin{array}{l}-2.803^{*} \\
(1.421)\end{array}$ & $\begin{array}{l}-2.678^{*} \\
(1.451)\end{array}$ & $\begin{array}{l}-2.723 * \\
(1.437)\end{array}$ & $\begin{array}{l}-2.671^{*} \\
(1.461)\end{array}$ & $\begin{array}{l}-2.719 * \\
(1.414)\end{array}$ & $\begin{array}{c}-2.690^{*} \\
(1.398)\end{array}$ \\
\hline Population growth & $\begin{array}{c}-0.412 * * \\
(0.152)\end{array}$ & $\begin{array}{c}-0.428^{* *} \\
(0.159)\end{array}$ & $\begin{aligned}-0.422^{* *} \\
(0.155)\end{aligned}$ & $\begin{array}{c}-0.433^{* *} \\
(0.150)\end{array}$ & $\begin{array}{c}-0.424^{* *} \\
(0.155)\end{array}$ & $\begin{array}{c}-0.428^{* *} \\
(0.150)\end{array}$ \\
\hline Investment rate & $\begin{array}{c}0.049 \\
(0.029)\end{array}$ & $\begin{array}{c}0.044 \\
(0.030)\end{array}$ & $\begin{array}{c}0.047 \\
(0.030)\end{array}$ & $\begin{array}{c}0.042 \\
(0.030)\end{array}$ & $\begin{array}{c}0.039 \\
(0.031)\end{array}$ & $\begin{array}{c}0.038 \\
(0.031)\end{array}$ \\
\hline $\begin{array}{l}\text { Working age population with } \\
\text { higher education, } \%\end{array}$ & $\begin{array}{l}0.063^{* *} \\
(0.029)\end{array}$ & $\begin{array}{l}0.058^{*} \\
(0.030)\end{array}$ & $\begin{array}{l}0.060^{*} \\
(0.029)\end{array}$ & $\begin{array}{l}0.058^{*} \\
(0.029)\end{array}$ & $\begin{array}{l}0.059 * \\
(0.029)\end{array}$ & $\begin{array}{l}0.059 * \\
(0.028)\end{array}$ \\
\hline Agricultural employment rate & $\begin{array}{c}-0.068^{* *} \\
(0.025)\end{array}$ & $\begin{array}{c}-0.067^{* *} \\
(0.024)\end{array}$ & $\begin{array}{r}-0.067 * * \\
(0.025)\end{array}$ & $\begin{array}{c}-0.066 * * \\
(0.024)\end{array}$ & $\begin{array}{c}-0.065^{* *} \\
(0.025)\end{array}$ & $\begin{array}{c}-0.065 * * \\
(0.025)\end{array}$ \\
\hline Unemployment rate & $\begin{array}{l}-0.040 \\
(0.035)\end{array}$ & $\begin{array}{l}-0.039 \\
(0.037)\end{array}$ & $\begin{array}{l}-0.041 \\
(0.036)\end{array}$ & $\begin{array}{l}-0.039 \\
(0.036)\end{array}$ & $\begin{array}{l}-0.040 \\
(0.035)\end{array}$ & $\begin{array}{l}-0.039 \\
(0.035)\end{array}$ \\
\hline Total competences & $\begin{array}{c}0.038 \\
(0.048)\end{array}$ & & & & & \\
\hline Cumulated total competences & & $\begin{array}{c}0.000 \\
(0.003)\end{array}$ & & & & \\
\hline $\begin{array}{l}\text { Cumulated total competences } \\
\text { versus regional average }\end{array}$ & & & $\begin{array}{c}0.053 \\
(0.247) \\
\end{array}$ & & & \\
\hline Cumulated common competences & & & & $\begin{array}{c}0.000 \\
(0.026)\end{array}$ & & \\
\hline $\begin{array}{l}\text { Common competences Index (CC } \\
\text { Index) }\end{array}$ & & & & & $\begin{array}{c}0.030 \\
(0.106) \\
\end{array}$ & \\
\hline $\begin{array}{l}\text { Weighted cumulated common } \\
\text { competences }\end{array}$ & & & & & & $\begin{array}{c}0.020 \\
(0.128) \\
\end{array}$ \\
\hline Constant & $\begin{array}{l}30.556^{* *} \\
(14.175)\end{array}$ & $\begin{array}{l}29.921^{*} \\
(14.482)\end{array}$ & $\begin{array}{l}30.240^{*} \\
(14.315)\end{array}$ & $\begin{array}{l}29.900^{*} \\
(14.655)\end{array}$ & $\begin{array}{l}30.316^{* *} \\
(14.211)\end{array}$ & $\begin{array}{l}30.082^{* *} \\
(14.068)\end{array}$ \\
\hline Number of instruments & 92 & 92 & 92 & 92 & 90 & 92 \\
\hline Arellano-Bond test order 1 & $\begin{array}{r}-2.590 \\
(0.01)\end{array}$ & $\begin{array}{l}-2.600 \\
(0.009)\end{array}$ & $\begin{array}{l}-2.590 \\
(0.01)\end{array}$ & $\begin{array}{l}-2.600 \\
(0.009)\end{array}$ & $\begin{array}{l}-2.620 \\
(0.009)\end{array}$ & $\begin{array}{l}-2.600 \\
(0.009)\end{array}$ \\
\hline Arellano-Bond test order 2 & $\begin{array}{l}0.770 \\
(0.44)\end{array}$ & $\begin{array}{c}0.740 \\
(0.457)\end{array}$ & $\begin{array}{c}0.740 \\
(0.462)\end{array}$ & $\begin{array}{c}0.740 \\
(0.457)\end{array}$ & $\begin{array}{c}0.730 \\
(0.464)\end{array}$ & $\begin{array}{c}0.750 \\
(0.455)\end{array}$ \\
\hline Sargan test & $\begin{array}{l}67.090 \\
(0.806)\end{array}$ & $\begin{array}{l}66.800 \\
(0.813)\end{array}$ & $\begin{array}{l}67.200 \\
(0.804)\end{array}$ & $\begin{array}{l}66.750 \\
(0.814)\end{array}$ & $\begin{array}{r}65.090 \\
(0.81)\end{array}$ & $\begin{array}{l}65.670 \\
(0.839)\end{array}$ \\
\hline Hansen test & $\begin{array}{c}9.470 \\
(1.000)\end{array}$ & $\begin{array}{c}3.360 \\
(1.000)\end{array}$ & $\begin{array}{c}2.960 \\
(1.000)\end{array}$ & $\begin{array}{c}8.750 \\
(1.000)\end{array}$ & $\begin{array}{c}5.760 \\
(1.000)\end{array}$ & $\begin{array}{c}7.190 \\
(1.000)\end{array}$ \\
\hline
\end{tabular}

Note: See the notes to Table 2. 
growth. In the case of cumulated total powers $v s$. the regional average (column 3 ), a positive but not significant impact arises, which may suggest that if a region has a higher degree of autonomy than the average, it would grow at a relatively higher pace than the rest.

In column 5, we introduced the CC Index in the estimation. Again, the impact is positive, but statistically insignificant. Finally, in column 6, we worked with weighted cumulated common competencies, obtaining the same result: a positive effect on GDP per capita growth, which fails to appear significantly.

\subsection{Marginal effects of explanatory variables, according to the Common Competences Index}

The Spanish regions have competences on supply-side policies such as public investment, education, entrepreneurship, and research, development and innovation. Thus, it is interesting to analyse the direct effect of these variables on GDP per capita growth and their marginal effect, when we consider the different degree of regional autonomy as measured by the CC Index (Table 4). This could shed light on the achievements of regional policy on variables of its influence.

In column 1, an interaction between the CC Index and the investment rate was introduced. In this case, the coefficients for both variables become negative, with the interaction term being positive, but not statistically significant. Figure 3 represents the value of the marginal effect according to the CC Index. The marginal effect of the investment rate is slightly above zero for regions with low CC Index, increasing the positive effect as the CC Index rises. It could suggest that having more decentralised powers has a positive effect on investment and its impact on growth.

In the case of education, we used the percentage of working age population with higher education (column 2) and the average years of schooling (column 4). For the first one, it does not seem to have a complementarity, being the coefficient of the interaction positive but nearly zero (Figure 4). The effect does not vary depending on the existence of more or less autonomy. On the other hand, when the average years of schooling are used, the interaction is positive, though not statistically significant, and the marginal effect is almost zero regardless of the value of the CC Index (Figure 5). According to this, regional education policy does not seem to have a differential impact in regions with higher or lower number of transferred powers, while human capital in general bears a positive and statistically significant impact on GDP per capita growth.

Another relevant determinant of GDP per capita is entrepreneurship, as can be seen in column 5 of Table 4. To proxy this variable, we use the entrepreneurship 


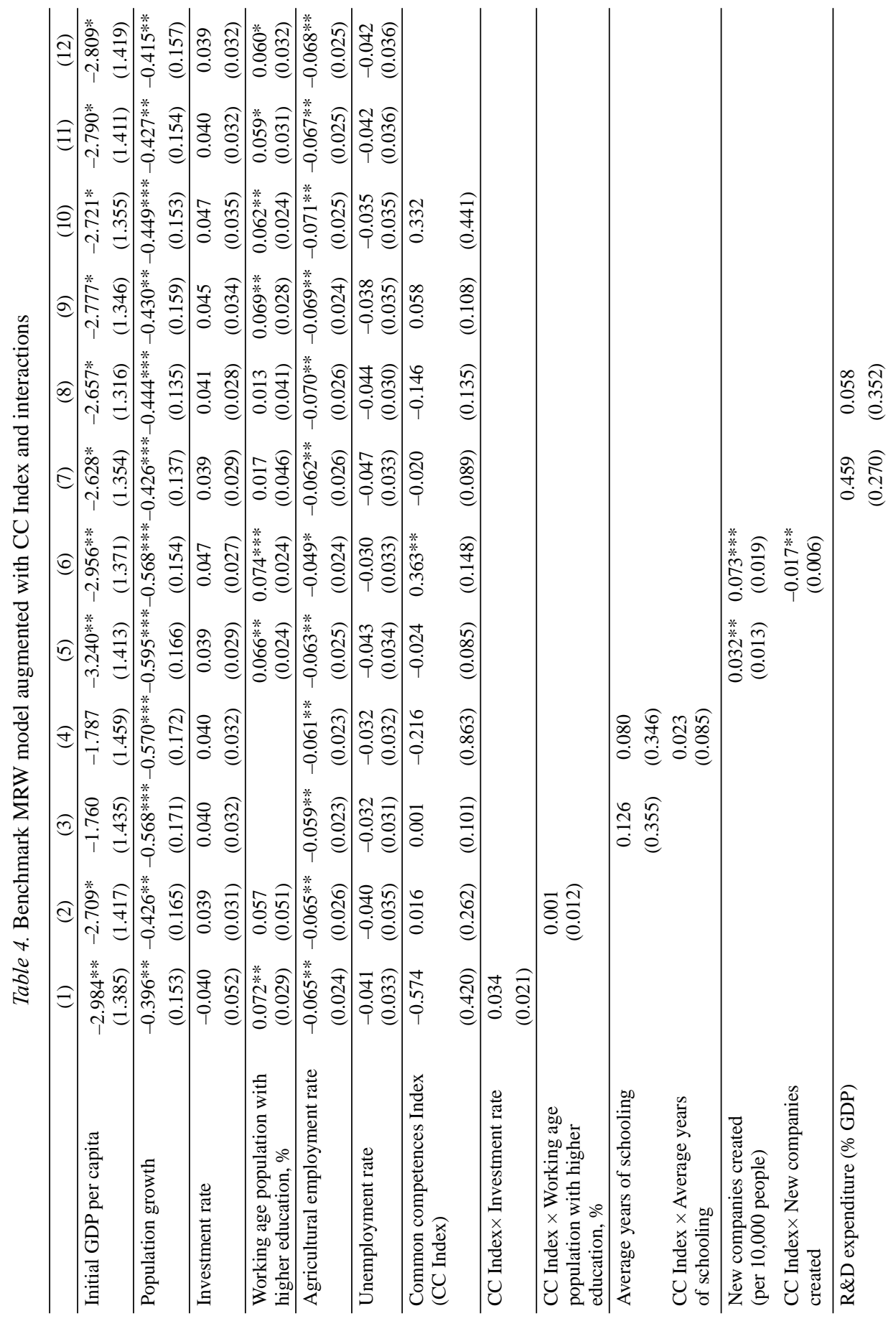




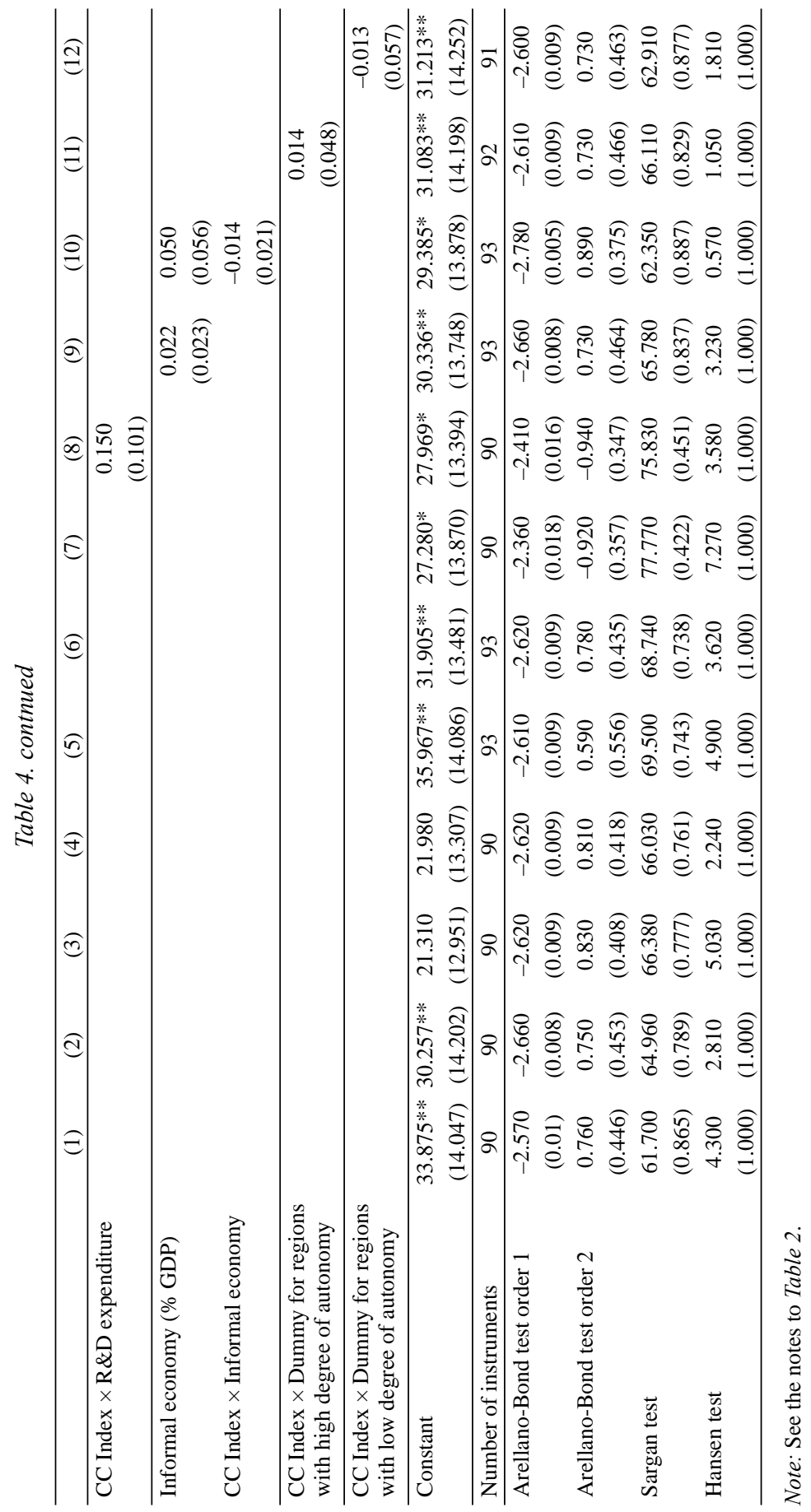



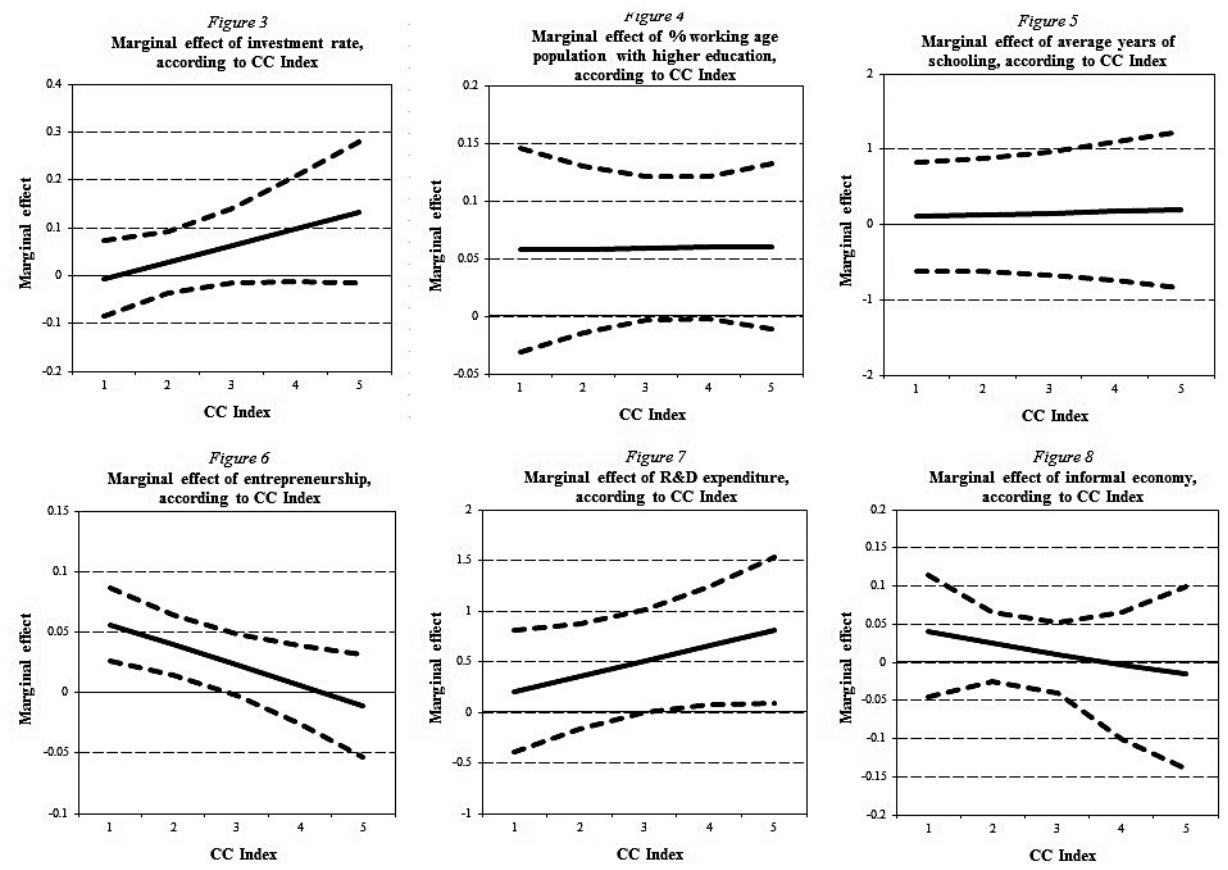

rate, measured as the number of new companies created (per 10,000 people). A positive and statistically significant coefficient is obtained. We then analyse if the degree of regional autonomy has any kind of interaction with the entrepreneurship rate to explain GDP per capita growth (column 6), being the coefficient of the interaction negative and statistically significant.

The results show that as decentralisation increases, the marginal effect of entrepreneurship decreases, although just slightly (Figure 6). Or the other way round, when the entrepreneurship rate is high enough (around 21 new companies created per 10,000 people), the marginal effect of CC Index would be zero, and it would have a negative impact on GDP per capita growth for higher values. This could suggest that perhaps an economy with a high entrepreneurship rate would not need additional policy action to generate positive effects on GDP growth.

Innovation is another key variable for regional policymakers. When we introduce the R\&D expenditure as percentage of GDP, the estimated coefficient is positive, as expected, although statistically insignificant (column 7). A positive complementarity is also observed when we interact this variable with the CC Index (column 8). Furthermore, it appears that a higher degree of decentralisation fosters the positive effect of the R\&D expenditure (Figure 7). 
One possible extension that can be considered, due to its relative importance in the Spanish economy, is the impact of the informal economy and its potential interaction with the level of regional autonomy. A positive relationship is found, though statistically insignificant, between the level of informal economy and GDP per capita growth (column 9), which can be explained by the fact that the informal economy accounts, on average, for nearly one-quarter of the Spanish GDP, generating several possible connections with the rest of the economy. Nevertheless, when we consider the interaction with the CC Index, the coefficient appears to be negative, so that when decentralisation reaches its maximum level, the marginal effect of the informal economy becomes negative (Figure 8). In contrast, when the CC Index takes value 1, the marginal effect remains positive. Thus, it seems that having more regional autonomy could discourage the informal economy in the sense that it would not have a positive impact on GDP per capita growth.

Finally, we have decomposed the CC Index into two variables, one that contains regions with higher degree of autonomy, and the rest (columns 11 and 12, respectively). As we expected, the complementarity is positive in the case of regions which accessed sooner to a higher level of decentralised powers, while it is negative for the rest of the regions. In any case, neither of the coefficients is statistically significant.

\section{CONCLUSIONS}

We analysed the convergence and growth process of Spanish regions since the beginning of the decentralisation process in the early 1980s. For that purpose, a dynamic panel data analysis was conducted applying the system GMM estimator.

In the benchmank specification, which corresponds to the regression of GDP per capita growth conditioned on the initial level of GDP per capita, population growth, the non-residential investment rate, the rate of working age population with higher education, and the control variables (rate of agricultural employment and unemployment rate), a statistically significant and negative sign is obtained for the initial GDP per capita level. This would confirm the existence of a process of catching-up among the regions, but at a very low pace. In conclusion, the regional convergence policy did not have the expected success. Population growth has the expected negative effect, as the Solow model predicts, while human capital seems to foster growth. In the case of the investment rate, the estimated coefficient is positive, though it is not statistically significant. Finally, both control variables present negative coefficients, which suggests that having a high proportion of employment in the primary sector and a high unemployment rate is a drag on growth, lowering the steady-state levels. Therefore, in general, the 
empirical evidence for Spanish regions confirms the expected results, also rendering a positive contribution of innovation and entrepreneurship, key elements for regional policymakers.

For the sake of robustness, the process of transfer of powers was proxied by several indicators that took into account the total number of competences assumed by regional governments, or just the powers that are considered common. In particular, we built a CC Index that ranges between 1 and 5, trying to measure the degree of autonomy of a region. Overall, it seems that the capacity of a region to implement policies has a positive contribution to GDP per capita growth, although the results are not statistically significant. Further extensions of that index considering a wider definition of decentralisation would need to be investigated.

We have tried to shed light on the achievement of regional policy. We have selected four areas: public investment, education, entrepreneurship, and research, development and innovation. We have analysed the direct effect of these variables on GDP per capita growth and their marginal effect, when we consider the different degree of regional autonomy measured by the CC Index. In general, it seems that a higher number of decentralised powers involves a stronger positive effect of the indicators on GDP per capita growth, with the exception of entrepreneurship, whose positive effect would fade and even become neutral, but just when the CC Index takes the upper value.

Another possible extension that we have considered interesting, due to its relative importance in the Spanish economy, is the impact of the informal economy and its potential interaction with the level of regional autonomy. A slightly positive relationship between the level of informal economy and GDP per capita growth is found. Nevertheless, when we consider the interaction with the CC Index, it appears to be negative, so that when the decentralisation reaches its maximum level, the marginal effect of the informal economy becomes negative.

When we decompose the CC Index into two variables, one that contains the regions with higher degree of autonomy, and the rest, as expected, we obtain a positive complementarity in the case of the regions which accessed sooner to a higher level of competences, while it is negative for the rest of the regions. In any case, neither of the coefficients is statistically significant. Again, the emphasis on decentralisation to foster regional growth is not clearly supported. In sum, our empirical analysis concludes that this factor does not significantly affect economic growth.

Our analysis invites further research on these uncovered relationships between regional growth and the process of transfer of powers, using alternative data and methods, for example, by introducing spatial econometrics. The renewed interest in the analysis of regional growth and convergence deserves further deepening in this type of analysis, from all possible perspectives. 


\section{REFERENCES}

Arellano, M. - Bover, O. (1995): Another Look at the Instrumental Variable Estimation of ErrorComponents Models. Journal of Econometrics, 68(1): 29-51.

Asatryan, Z. - Feld, L. P. (2015): Revisiting the Link between Growth and Federalism: A Bayesian Model Averaging Approach. Journal of Comparative Economics, 43(3): 772-781.

Bajo-Rubio, O. - Díaz-Roldán, C. (2015): Economic Growth and the Balance-of-Payments Constraint: The Case of the Spanish Regions, 1988-2009. Acta Oeconomica, 65(4): 617-629.

Barro, R. J. (1990): Government Spending in a Simple Model of Endogenous Growth. Journal of Political Economy, 98(5): S103-S125.

Barro, R. J. - Sala-i-Martin, X. (1991): Convergence across States and Regions. Brookings Papers on Economic Activity, 1: 107-182.

Blundell, R. W. - Bond, S. R. (1998): Initial Conditions and Moment Restrictions in Dynamic Panel Data Models. Journal of Econometrics, 87(1): 115-143.

Brambor, T. - Clark, W. R. - Golder, M. (2006): Understanding Interaction Models: Improving Empirical Analyses. Political Analysis, 14(1): 63-82.

Braumoeller, B. F. (2004): Hypothesis Testing and Multiplicative Interaction Terms. Industrial Organization, 58(4): 807-820.

Cantarero, D. - Pérez, P. (2009): Fiscal Decentralization and Economic Growth: Evidence from Spanish Regions. Public Budgeting \& Finance, 29(4): 24-44.

Carrion-i-Silvestre, J. L. - Espasa, M. - Mora, T. (2008): Fiscal Decentralization and Economic Growth in Spain. Public Finance Review, 36(2): 194-218.

Castles, F. G. (1999): Decentralisation and the Post-War Economy. European Journal of Political Research, 36(1): 27-53.

Davoodi, H. - Zou, H. F. (1998): Fiscal Decentralization and Economic Growth. A Cross-Country Study. Journal of Urban Economics, 43(2): 244-257.

De La Fuente, A. (2002): On the Sources of Convergence: A Close Look at the Spanish Regions. European Economic Review, 46(3): 569-599.

De La Fuente, A. - Doménech, R. (2016): El Nivel Educativo de la Población en España y sus Regiones: 1960-2011. Investigaciones Regionales - Journal of Regional Research, 34: 73-94.

Durlauf, S. N. - Johnson, P. - Temple, J. (2005): Growth Econometrics. In: Aghion, P. - Durlauf, S. N. (eds): Handbook of Economic Growth. Volume 1, Part A, North-Holland, Amsterdam, pp. 555-677.

Ezcurra, R. - Rodríguez-Pose, A. (2013): Political Decentralization, Economic Growth and Regional Disparities in the OECD. Regional Studies, 47(3): 388-401.

Filippetti, A. - Sacchi, A. (2016): Decentralization and Economic Growth Reconsidered: The Role of Regional Authority. Environment and Planning C: Government and Policy, 34(8): 17931824.

Friedrich, R. J. (1982): In Defence of Multiplicative Interaction Terms in Multiple Regression Equations. American Journal of Political Science, 26(4): 797-833.

Fundación Bancaja and IVIE (2014): Capital Humano en España y su Distribución Provincial. January.

Fundación BBVA and IVIE (2014): El Stock y los Servicios del Capital en España y su Distribución Territorial y Sectorial (1964-2012). June.

GESTHA - FURV (2014): La Economía Sumergida pasa Factura. El Avance del Fraude en España durante la Crisis. Sindicato de Técnicos del Ministerio de Hacienda (GESTHA) - Fundación Universidad Rovira i Virgili (FURV), Madrid. 
Gil-Serrate, R. - López-Laborda, J. (2006): Revenue Decentralisation and Economic Growth in the Spanish Autonomous Communities. 46 $^{\text {th }}$ European Regional Science Association Conference Papers, Volos, Greece.

Gil-Serrate, R. - López-Laborda, J. - Mur, J. (2011): Revenue Autonomy and Regional Growth: An Analysis for the 25 Year-Process of Fiscal Decentralisation in Spain. Environment and Planning A, 43(11): 2626-2648.

Gómez-Antonio, M. - Alañón, A. (2004): Evaluación y Análisis Espacial del Grado de Incumplimiento Fiscal para las Provincias Españolas (1980-2000). Hacienda Pública Española, 171(4): 9-32.

González-Páramo, J. M. - Martínez-López, D. (2003): Convergence across Spanish Regions: New Evidence on the Effects of Public Investment. The Review of Regional Studies, 33(2): 184205.

Hernández-Salmerón, E. M. - Usabiaga, C. (2016): Análisis del Crecimiento Económico y la Convergencia: Aplicaciones para las Comunidades Autónomas Españolas. Cuadernos de Investigación, 6, Consejería de Hacienda y Administración Pública (Junta de Andalucía), Sevilla.

Ligthart, J. E. - Van Oudheusden, P. (2017): The Fiscal Decentralisation and Economic Growth Nexus Revisited. Fiscal Studies, 38(1): 141-171.

Lin, J. Y. - Liu, Z. (2000): Fiscal Decentralization and Economic Growth in China. Economic Development and Cultural Change, 49(1): 1-23.

Mankiw, G. - Romer, D. - Weil, D. (1992): A Contribution to the Empirics of Economic Growth. The Quarterly Journal of Economics, 107(2): 407-437.

Mas, M. - Maudos, J. - Pérez, F. - Uriel, E. (1993): Disparidades Regionales y Convergencia de las CC.AA Españolas. Instituto Valenciano de Investigaciones Económicas (IVIE), WP-EC 93-04.

Maudos, J. - Pastor, J. M. - Serrano, L. (1998): Convergencia en las Regiones Españolas: Cambio Técnico, Eficiencia y Productividad. Revista Española de Economía, 15(2): 235-264.

Rodden, J. (2004): Comparative Federalism and Decentralization: On Meaning and Measurement. Comparative Politics, 36(4): 481-500.

Rodríguez-Pose, A. - Bwire, A. (2004): The Economic (In)Efficiency of Devolution. Environment and Planning A, 36(11): 1907-1928.

Rodríguez-Pose, A. - Ezcurra, R. (2011): Is Fiscal Decentralization Harmful for Economic Growth? Evidence from the OECD Countries. Journal of Economic Geography, 11(4): 619-643.

Roodman, D. (2009a): How to Do xtabond2: An Introduction to Difference and System GMM in Stata. Stata Journal, 9(1): 86-136.

Roodman, D. (2009b): A Note on the Theme of too Many Instruments. Oxford Bulletin of Economics and Statistics, 71(1): 135-158.

Solow, R. M. (1956): A Contribution to the Theory of Economic Growth. The Quarterly Journal of Economics, 70(1): 65-94. 


\section{APPENDIX}

\section{Decentralisation and economic growth: A selection of empirical research}

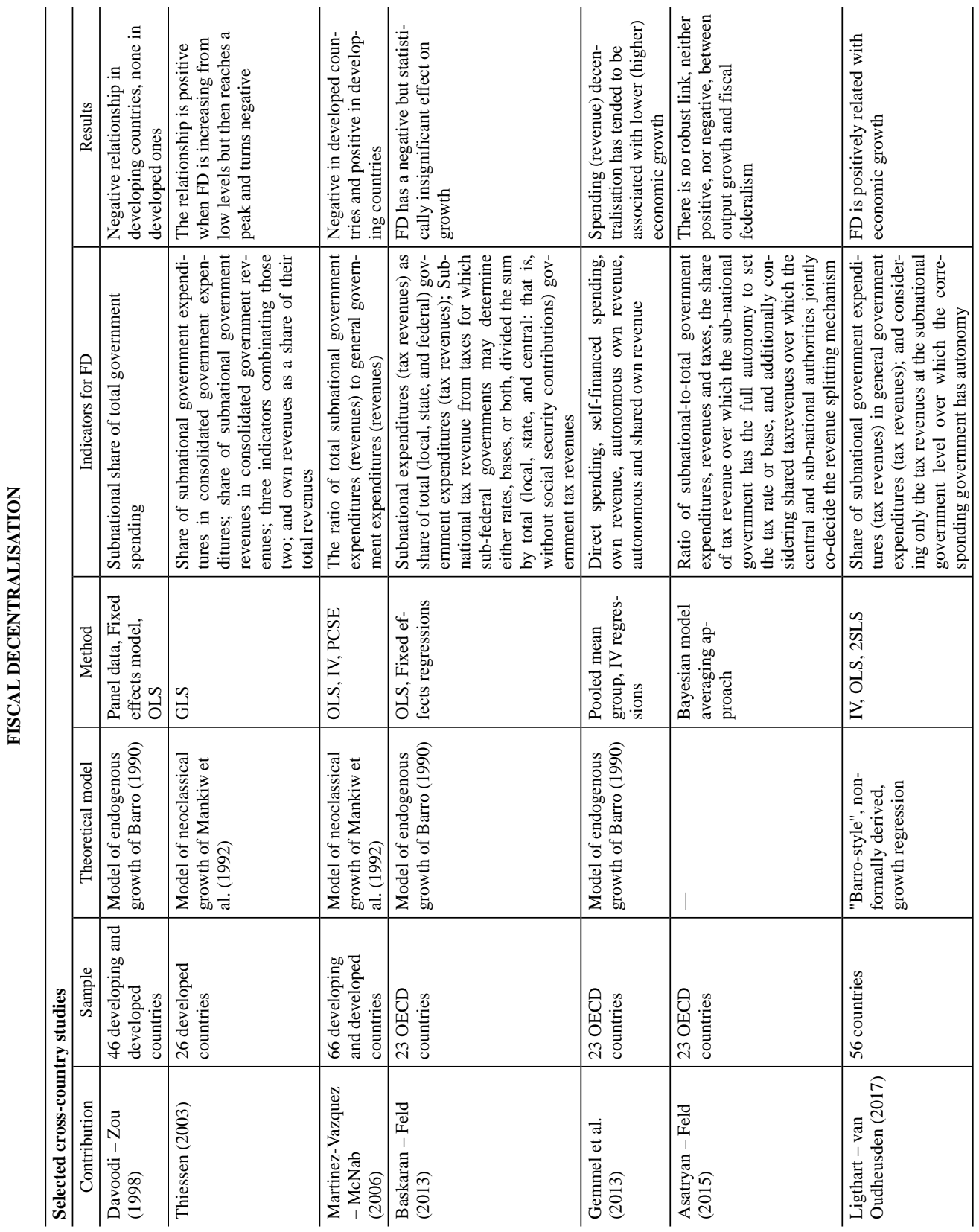




\begin{tabular}{|c|c|c|c|c|c|c|c|c|}
\hline & 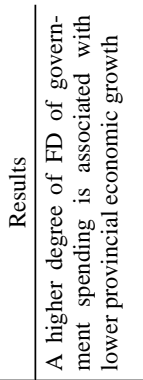 & 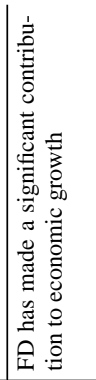 & 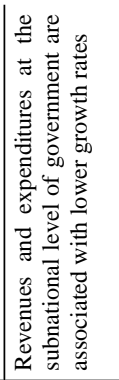 & 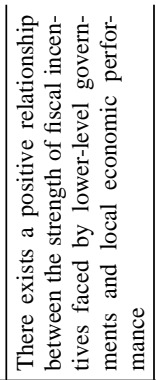 & 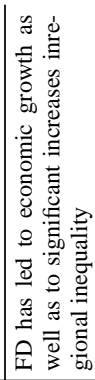 & 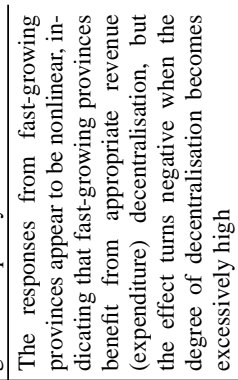 & 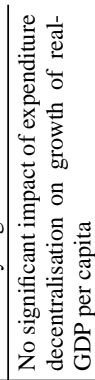 & 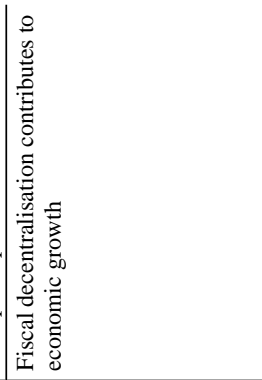 \\
\hline & 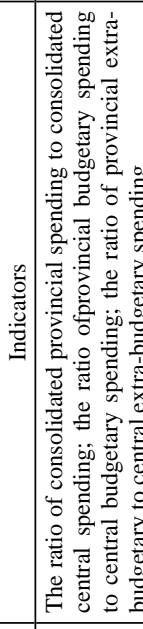 & 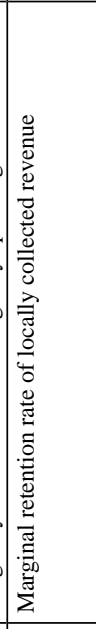 & 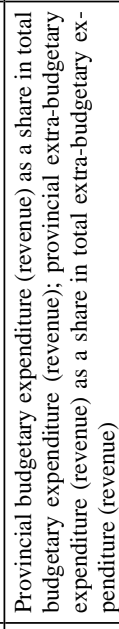 & 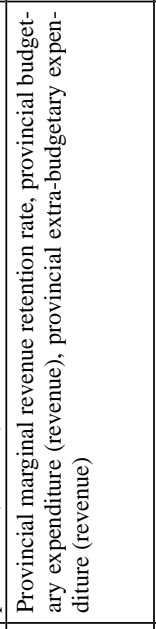 & 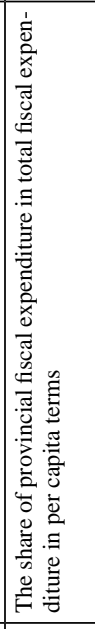 & 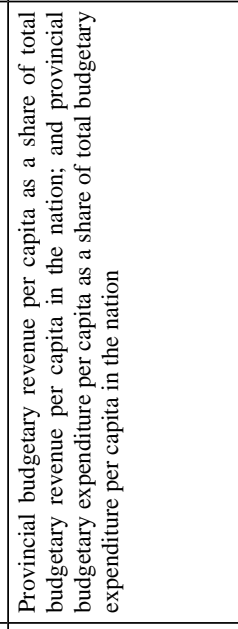 & 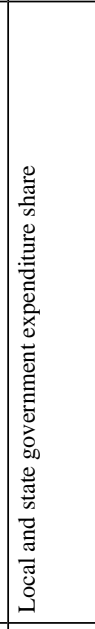 & 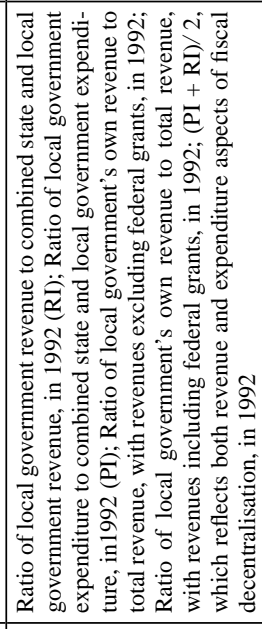 \\
\hline & 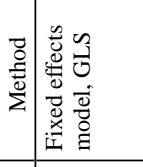 & 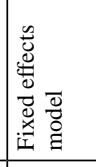 & 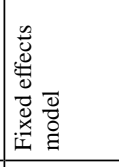 & 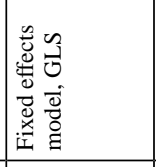 & 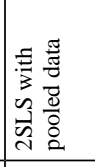 & 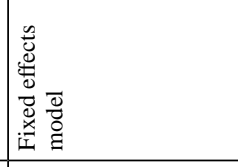 & 告 & 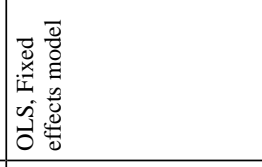 \\
\hline 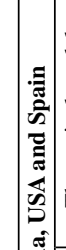 & 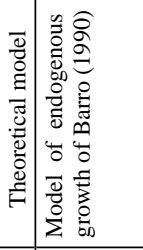 & 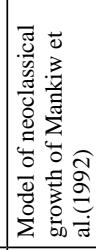 & 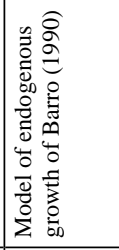 & 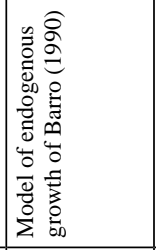 & 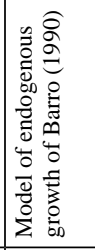 & 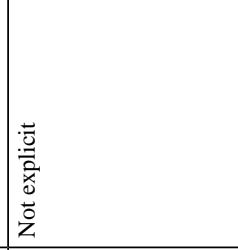 & 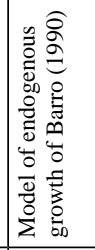 & 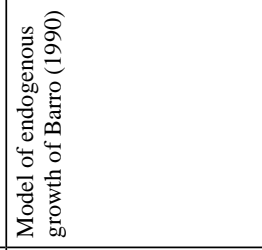 \\
\hline 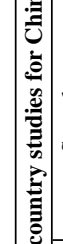 & 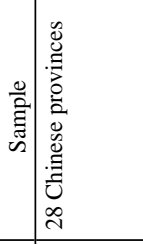 & 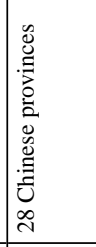 & 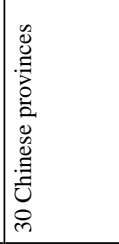 & 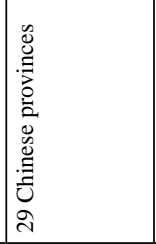 & 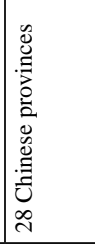 & 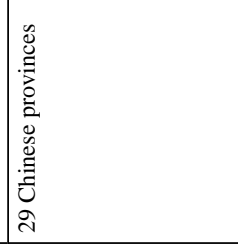 & 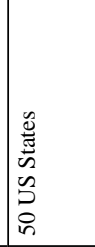 & 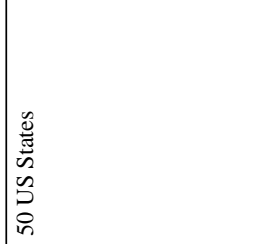 \\
\hline 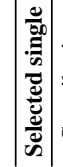 & 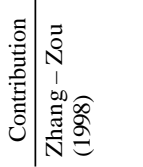 & 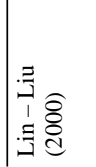 & 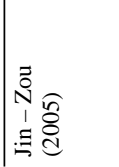 & 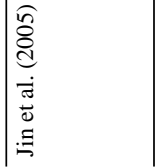 & 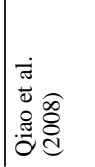 & 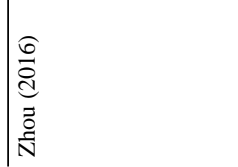 & 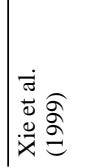 & 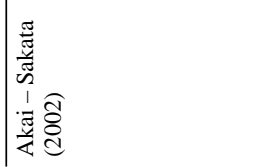 \\
\hline
\end{tabular}




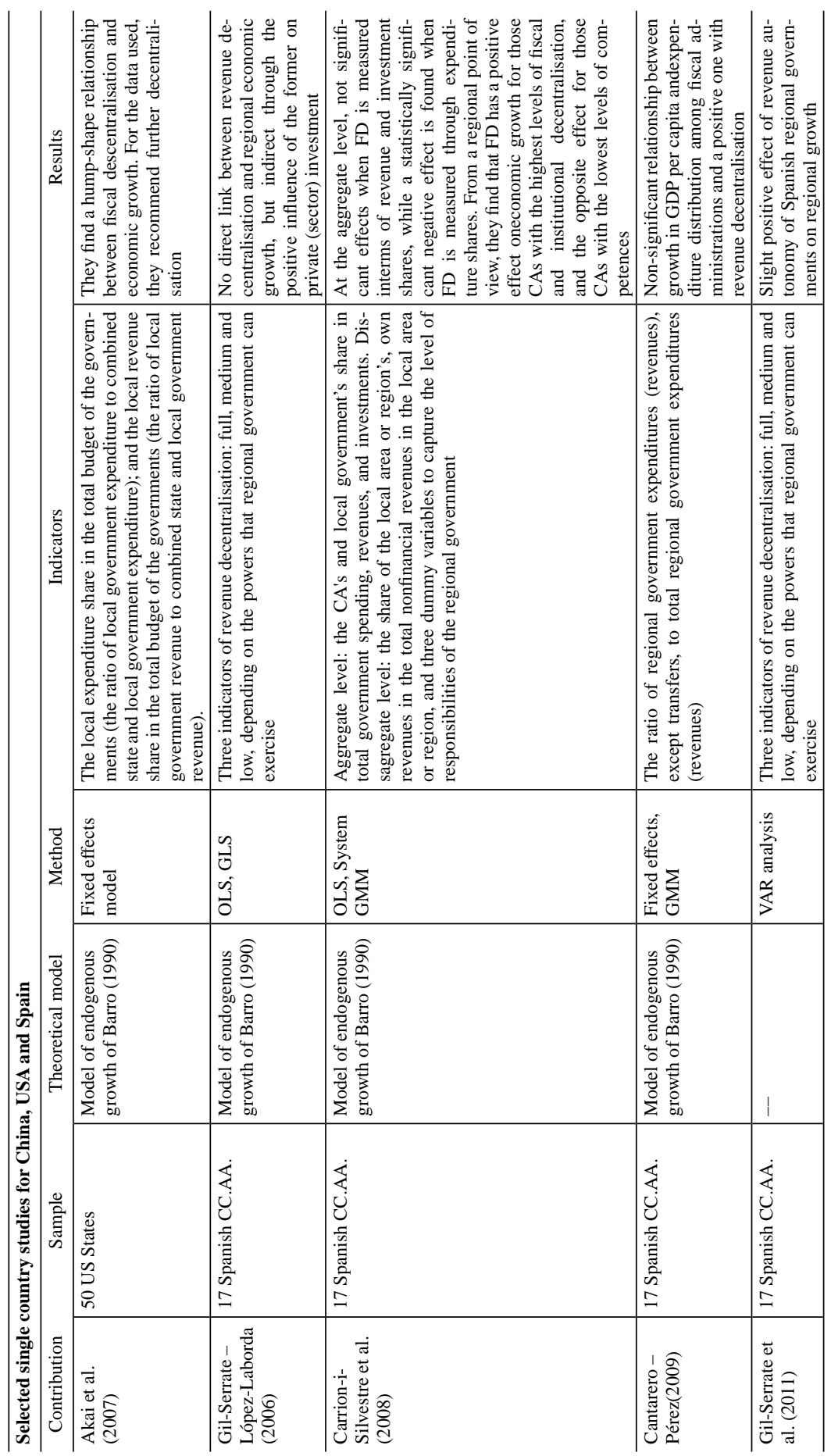




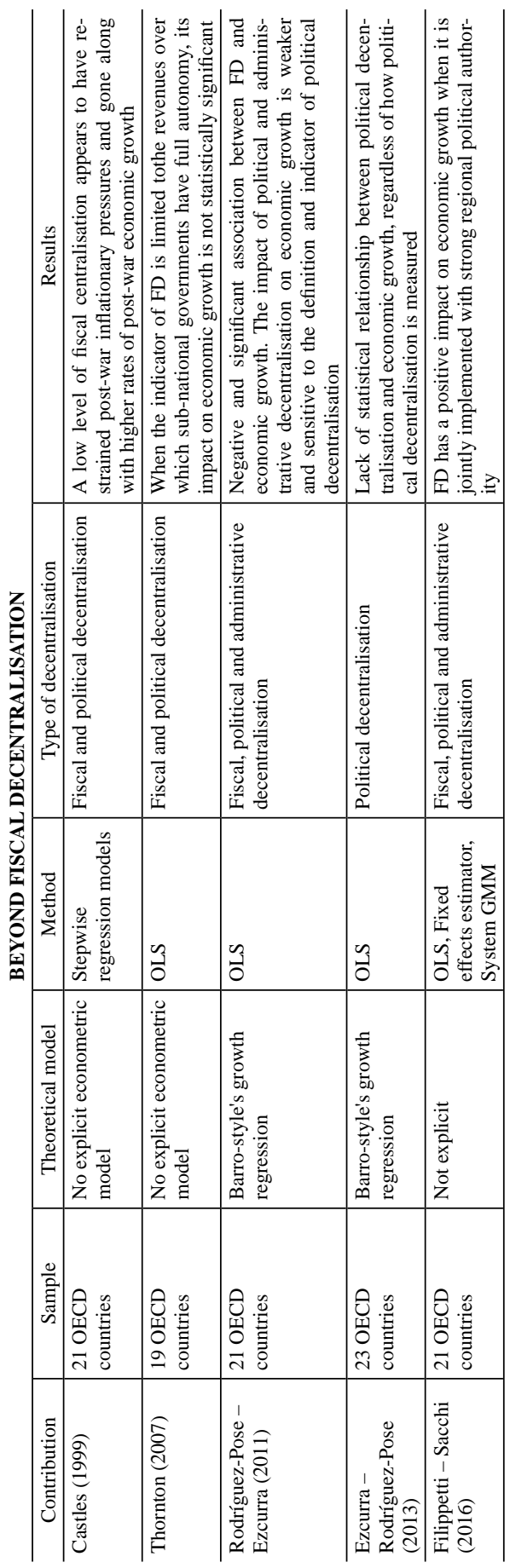

